\title{
Small-scale morphological and genetic differentiation in the Mediterranean killifish Aphanius fasciatus (Cyprinodontidae) from a coastal brackish-water pond and an adjacent pool in northern Sardinia
}

\section{Différentiation morphologique et génétique chez le Cyprinodonte méditerranéen Aphanius fasciatus d'un étang saumâtre et de sa mare adjacente, au nord de la Sardaigne (Italie)}

\author{
Ferruccio Maltagliati ${ }^{\mathrm{a}, *}$, Paolo Domenici ${ }^{\mathrm{b}}$, Clara Franch Fosch ${ }^{\mathrm{c}}$, Piero Cossu ${ }^{\mathrm{d}}$, \\ Marco Casu ${ }^{\mathrm{d}}$, Alberto Castelli ${ }^{\mathrm{a}}$ \\ ${ }^{a}$ Dipartimento di Scienze dell'Uomo e dell'Ambiente, Università di Pisa, Via A. Volta 6, 56126 Pisa, Italy \\ ${ }^{b}$ International Marine Centre, Località Sa Mardini, 09072 Torregrande (OR), Italy \\ ${ }^{c}$ Departament de Biologia Animal, Universitat de Barcelona, Avenida Diagonal 645, 08028 Barcelona, Spain \\ ${ }^{d}$ Dipartimento di Zoologia e Antropologia Biologica, Università di Sassari Corso Margherita di Savoia, 15, 07100 Sassari, Italy
}

Received 31 July 2002; accepted 30 September 2002

\begin{abstract}
Two samples of Aphanius fasciatus collected in the Pilo pond (northern Sardinia, Italy) and in an adjacent pool of small surface area were analysed morphologically (235 individuals) and genetically (a subsample of 58 individuals). The aims of the present study were (i) to test the hypothesis that different predation pressures may be associated with morphological and/or genetic differences between samples from each habitat and (ii) to assess the level of divergence between the two populations. Morphological analysis was based on the relative size of fins because it has been shown to be associated with predation pressure. The relative caudal fin area (caudal fin area/total body surface) was smaller in specimens from the pool, in both males and females, whereas no differences were found for the dorsal and anal fin areas. Caudal fins with higher aspect ratio (fin depth/fin length) were found in fish from the pool but not in the pond, due to a higher fin depth. We hypothesised that specimens from the pool would show smaller caudal fin area, since they are subject to lower predation pressure. Random amplification of polymorphic DNA (RAPD) analysis revealed a relatively high degree of both within- and between-sample genetic heterogeneity. The pond and pool samples exhibited heterozygosities, which did not differ significantly by $t$-test. Between-sample genetic divergence was highlighted by the coancestry coefficient $(\theta=0.301 \pm 0.059, P<0.001)$ and analysis of molecular variance (AMOVA) (variance between sites $=41 \%$, $P<0.001)$. Genetic divergence between sites with a relatively high genetic diversity within both samples suggested that the population in the pool did not originate from a single colonisation event with a small number of founders. The genetic divergence between the two populations is consistent with their differences in fin size.
\end{abstract}

(C) 2003 Éditions scientifiques et médicales Elsevier SAS and Ifremer/CNRS/IRD. All rights reserved.

\section{Résumé}

Deux échantillons de l'espèce Aphanius fasciatus, collectés dans l'étang de Pilo (nord de la Sardaigne, Italie) et dans une mare voisine, ont été analysés morphologiquement (235 individus) et génétiquement (un sous-échantillon de 58 individus). Les objectifs sont : 1) de tester l'hypothèse selon laquelle des pressions de prédation différentes seraient associées à des différences morphologiques et/ou génétiques entre les échantillons de chaque habitat ; 2) de déterminer le niveau de divergence entre les deux populations. L'analyse morphologique est basée sur la taille relative des nageoires car il a été démontré qu'elle dépendait de la pression de prédation. La surface relative de la nageoire caudale (surface de la nageoire caudale/surface totale du corps) est plus petite chez les spécimens de la mare aussi bien chez les mâles que chez les

* Corresponding author

E-mail address: maltagli@discat.unipi.it (F. Maltagliati). 
femelles alors qu'aucune différence n'est trouvée pour les surfaces des nageoires dorsale et anale. Les nageoires caudales à l'aspect plus haut (profondeur/longueur) se rencontrent chez les poissons de la mare mais pas chez celle de l'étang. Nous supposions que les spécimens de la mare présenteraient une surface de la nageoire caudale inférieure puisqu'ils sont soumis à une moindre pression de prédation. Une analyse par la méthode random amplification of polymorphic DNA (RAPD) révèle un degré d'hétérogénéité génétique relativement élevé aussi bien au sein d'un échantillon qu'entre les échantillons. Les échantillons de l'étang et de la mare présentent des hétérozygoties qui ne diffèrent pas significativement en utilisant le test- $t$. La divergence entre échantillons est mise en lumière par le coefficient de co-lignage $(\theta=0,301 \pm 0,059$, $P<0,001$ ) et le test Amova (variance entre sites $=41 \%, P<0,001$ ). La divergence génétique entre sites avec une diversité génétique relativement élevée au sein des deux échantillons suggère que la population de la mare n'est pas issue d'une seule colonisation avec un faible nombre de fondateurs. La divergence génétique entre les deux populations est cohérente avec la différence de taille de leurs nageoires.

(C) 2003 Éditions scientifiques et médicales Elsevier SAS and Ifremer/CNRS/IRD. Tous droits réservés.

Keywords: Morphology; Relative fin size; Genetic variation; RAPDs; Population divergence; Brackish-water habitats

Mots clés : Morphologie ; Taille relative des nageoires ; Variation génétique ; Divergence de populations ; Eaux saumâtres

\section{Introduction}

The population structure of brackish-water species has attracted considerable interest, not only because of its importance for the management of lagoon or estuarine fisheries, but also because of fundamental interest for the comprehension of the evolutionary mechanisms of differentiation and, ultimately, speciation driven by the peculiar characteristics of these environments (e.g. see Cognetti and Maltagliati, 2000). In fact, brackish-water habitats are characterised by rapid and wide changes of both physical-chemical and biological features due to natural events, as well as humaninduced alterations (Cognetti, 1994). This determines peculiarities in biodiversity of brackish-water habitats from community to individual levels (reviewed in Cognetti, 1994; Cognetti and Maltagliati, 2000). At infraspecific level, the reduction of the effective population size, genetic drift, inbreeding and founder effect may produce loss of genetic diversity and drive population differentiation at both morphological and genetic level (Hartl and Clark, 1997). A bulk of papers report evidence of moderate to high levels of morphological and genetic diversity among populations of brackish-water organisms (e.g. see Muus, 1967; Kolding, 1985; Cognetti, 1994; Kirchhoff et al., 1999; Ferrito et al., 2003). The naturally fragmented nature of brackish-water habitats and the common eco-biological characteristics, such as the absence of dispersal stages or habitat fidelity, account for the restricted or null gene flow occurring among populations of most of typical brackish-water species.

In the present study the population structure of the killifish Aphanius fasciatus Nardo 1827, from Pilo pond (Northern Sardinia, Italy) and an adjacent pool was investigated using morphological analysis and random amplified polymorphic DNA markers (RAPDs). A. fasciatus is a Mediterranean endemic cyprinodont with broad thermal and salinity tolerances. This fish is, therefore, adapted to inhabit a variety of environments. Despite this, it is usually found in brackishwater habitats, such as coastal ponds or lagoons where it performs the whole life cycle. Life history traits of A. fasciatus include large benthic eggs and absence of pelagic larval stages, thus the species has limited potential for dispersal. As a consequence, gene flow among local populations is restricted (Maltagliati, 1998a, b, 1999). The high degree of isolation among populations results in marked genetic structuring and morphological differentiation (Kiener and Schachter, 1974; Parenti and Tigano, 1993; Maltagliati, 1999; Ferrito et al., 2003). A. fasciatus populations have declined dramatically, in a few cases even to extinction, due to problems such as brackish-water habitat degradation, pollution of continental and coastal waters, destruction and reduction of salt-works, or introduction of exotic fishes (Bianco, 1995). As a consequence, A. fasciatus has been listed in the Annexes II and III of the "Bern Convention", relative to the conservation of wildlife and natural environment in Europe (Council of Europe, 2000) and in the Annexe II of the 'Fauna-Flora-Habitat' 92/43/CEE Directive, concerning conservation of natural habitats and wild flora and fauna of the European Union (Council of Europe, 1992). Furthermore, A. fasciatus was recently listed in the International union for conservation of nature and natural resources Red Data Book of endangered species (Baillie and Groombridge, 1996), where it was qualified as "data deficient", namely a species for which information is not sufficient to make a direct or indirect assessment of its conservation status. Nevertheless, recent studies showed that in A. fasciatus the overall genetic diversity of the species is almost completely determined by the among-population rather than withinpopulation genetic variability (Maltagliati, 1998a, b, 1999). This confirmed, therefore, the need to preserve it because natural patterns of variation that result in low local population genetic diversity but high among-population variability are indicative of species vulnerability (Meffe and Vrijenhoek, 1988). In fact, the deleterious effects of genetic losses caused by dramatic reductions of the effective population sizes may represent a risk to which A. fasciatus is subjected (e.g. see Maltagliati, 2002).

Morphological analyses can be a tool to assess habitatspecific differentiation related to the different predation pressures in fish and other lower vertebrates such as tadpoles (Bronmark and Miner, 1992; McCollum and Van Buskirk, 1996). Previous work showed that the presence of a predator 
can induce large tail (i.e. about 5-15\% larger than in the absence of predators) in larval anurans (Smith and Van Buskirk, 1995). Such predator-induced morphology is associated with decreased vulnerability to predation (McCollum and Van Buskirk, 1996). Previous work and theory based on functional morphology suggests that fish that are specialised for unsteady swimming, such as that used in brief predatorprey encounters, show morphological features that trade off with specialisation for continuous swimming such as that used for migration of food search (Webb, 1984; Domenici, 2003). Such morphological features include a higher percentage of anaerobic muscle mass, and large tail area for thrust maximisation and a flexible body in unsteady swimmers, versus a high percentage of aerobic muscle mass, a tail with high aspect ratio (fin depth/fin length) and small area for drag minimisation and a rigid body to minimise recoil, and therefore, drag (Webb, 1984). For this reason, we used tail size as an indicator of morphological specialisation for unsteady versus steady swimming. Although large tails in larval anurans exposed to predation pressure have been suggested to increase escape swimming performance (McCollum and Van Buskirk, 1996), recent studies have shown no difference in swimming performance between tadpoles with large tail versus tadpoles with small tails. Therefore, other mechanisms to decrease vulnerability in large-tailed fish have been proposed (Van Buskirk and McCollum, 2000). In addition we have also measured fin size in dorsal and anal. As a large body depth is suggested to improve escape swimming performance when distributed as far as possible from the centre of mass (Webb, 1978), we do not expect that different predation pressure would have a significant effect of anal and dorsal fins.

The aims of the present study were (1) to test the hypothesis that different predation pressures in these habitats may be associated with morphological and/or genetic differences between samples from each habitat and (2) to assess the level of divergence between the two populations.

\section{Materials and methods}

\subsection{Samples}

Killifish specimens were collected at Pilo pond and an adjacent pool about $10 \mathrm{~m}$ distant from the pond on June 2000. The pool is circular-shaped with a diameter of about 7-8 m. The Pilo pond is a coastal brackish-water basin located in Northern Sardinia $\left(40^{\circ} 51^{\prime} \mathrm{N} ; 8^{\circ} 17^{\prime} \mathrm{E}\right)$ with a surface area of roughly 120 ha. It is connected with the sea by a narrow canal with the mouth silted during most of the year. The major input of freshwater is furnished by two permanent and several transitory small inlets. Samples were preserved in $70 \%$ ethanol until analyses. Fish predators, such as the seabass, Dicentrarchus labrax, are present in the pond but are absent in the pool. On the other hand, although predation by birds cannot be excluded in the pool, the abundant vegetation compared to that of the pond may provide more refuge against aerial predators.

\subsection{Morphological analysis}

The specimens collected for morphological measurements were 48 females and 44 males from the pond, and 48 females and 95 males from the pool. Fish were measured using a calliper to the nearest millimetre. Fish total length, and the length of the anal, caudal and dorsal fins were measured. Fish were weighted using a precision laboratory balance. Fin and total body area were measured by covering these surfaces with aluminium foil and cutting it along the edges of each surface. Surface areas were then calculated by comparing the weight of each foil to that of a square foil of reference, with a known surface area.

The morphological parameters used for analysis were relative tail length $T_{\mathrm{L}}$ (tail length/total length), relative tail depth $T_{\mathrm{D}}$ (tail depth/total length), tail aspect ratio AR (tail depth/tail length), relative tail area $T_{\mathrm{A}}$ (tail area/total body area), relative dorsal fin area $D_{\mathrm{A}}$ (dorsal fin area/total wetted area) and relative anal fin area $A_{\mathrm{A}}$ (anal fin area/total wetted area). In addition, in order to avoid any possible bias in the total body area due to the reproductive status of females, the surface parameters were also standardised relative to Length $^{2}$. Therefore, the indices $T_{\mathrm{A}}$ (tail area/Length ${ }^{2}$ ), $D_{\text {A }}^{\prime}$ (dorsal fin area/Length ${ }^{2}$ ) and $A_{\mathrm{A}}^{\prime}$ ( anal fin area/Length ${ }^{2}$ ) were calculated.

Statistical analyses were carried out by using the software Statistica 5.1 (StatSoft, 1997). One-way Anovas and twoway factorial Anova including gender and location as factors were carried out.

\subsection{Genetic analysis}

Total genomic DNA was extracted from epaxial muscular tissue (20-25 mg) using the Qiagen ${ }^{\circledR}$ DNeasy Tissue kit. Screening for variable RAPD markers was conducted on 66 individuals from both the pond and pool using 20 standard RAPD 10-mer primers from the Operon Technologies ${ }^{\circledR}$, California and Genset $\mathrm{SA}^{\circledR}$, France. Samples were amplified in $25 \mu \mathrm{l}$ reaction mixtures containing $1 \times$ PCR buffer (Pharmacia $^{\circledR}$ ), $3 \mathrm{mM} \mathrm{MgCl}_{2}, 0.2 \mu \mathrm{M}$ primer, up to $40 \mathrm{ng}$ of genomic DNA, $200 \mu \mathrm{M}$ of each dNTP $\left(\right.$ Roche $\left.^{\circledR}\right)$ and $1 \mathrm{u}$ of Taq DNA Polymerase $\left(\right.$ Pharmacia $\left.^{\circledR}\right)$. Amplification was performed in a MJ PTC-100 Thermal Cycler (MJ Research ${ }^{\circledR}$ ) programmed for 45 cycles of $1 \mathrm{~min}$ denaturation at $94{ }^{\circ} \mathrm{C}$, 1 min low stringency annealing at $36{ }^{\circ} \mathrm{C}$ and 1 min primer extension at $72{ }^{\circ} \mathrm{C}$ to complete partial amplifications. At the end a final extension for 5 min was performed at $72{ }^{\circ} \mathrm{C}$. RAPD-PCR products were electrophoresed in $1.5 \%$ agarose gels in $1 \times$ TAE buffer $(0.04 \mathrm{M}$ Tris-acetate, and $0.001 \mathrm{M}$ EDTA). Gels were run at $50 \mathrm{~V}$ for about $3 \mathrm{~h}$ and placed in ethidium bromide $(1 \mu \mathrm{l} / 10 \mathrm{ml})$ for $15 \mathrm{~min}$. DNA fragments were visualised using a Photo-UV transilluminator system and recorded by digital photography. Double stranded DNA molecular weight standards (0.12-21.2 kbp DNA Molecular Weight Marker III and DNA Molecular Weight Marker XIV 100 base pairs (bp) ladder, Roche ${ }^{\circledR}$ ) were run on each gel in order to estimate and score the size of the PCR fragments. 
Table 1

Primer names and sequences, number of polymorphic bands per primer and range of molecular weight in base pairs (bp) amplified by PCR-RAPD for 58 individuals of $A$. fasciatus

\begin{tabular}{lllc}
\hline Primer & Sequence (5'-3') & $\begin{array}{l}\text { Number of } \\
\text { polymorphic bands }\end{array}$ & $\begin{array}{c}\text { Range of molecular } \\
\text { weight (bp) }\end{array}$ \\
\hline R2 & CGGCAAGCTC & 5 & $1000-3000$ \\
R3 & ACACTTGCAG & 3 & $1000-3500$ \\
C-07 & GTCCCGACGA & 5 & $900-3000$ \\
C-08 & TGGACCGGTG & 3 & $1500-2600$ \\
C-11 & AAAGCTGCGG & 4 & $400-1500$ \\
C-14 & TGCGTGCTTG & 2 & $400-800$ \\
C-16 & CACACTCCAG & 3 & $1100-4000$ \\
C-18 & TGAGTGGGTG & 3 & $600-1200$ \\
\hline
\end{tabular}

Primers that yielded scorable bands were also tested in a second run with the same samples of DNA from individuals used in the first run to test for reproducibility of bands within individuals and between runs. The eight primers that gave the best amplification products in terms of band resolution were selected Table 1]. Negative control was run with each primer to ensure that scorable fragments were not artefacts. Each variable band was scored as present (1) or absent (0) and was considered to represent the phenotype of a distinct locus. We took a conservative approach to scoring by choosing only distinct, intense, and reproducible bands.

RAPD patterns generated by variable primers were analysed directly as phenotypes. RAPD bands are dominant markers, therefore, the dominant allele determines the presence of the band such that $+/+$ and $+/-$ individuals have the (1) phenotype whereas $-/$ - individuals have the (0) phenotype. We assumed that all variable bands had this property and that bands were not allelic. In addition, we assumed that the population of the pool was in Hardy-Weinberg equilibrium (HWE). The population of the pond has previously been tested with a recent allozyme study and demonstrated to be in HWE (Maltagliati, 2002). Allele frequencies, heterozygosity $(H)$ and jack-knifed $F$-statistics values were obtained using the program Tools for population genetic analyses (TFPGA) (Miller, 1997), applying the method outlined by Lynch and Milligan (1994). The differences between average heterozygosities were tested for significance by $t$-tests of arcsine square-root transformed values of single locus $H$ (Archie, 1985). Two tailed $t$-test was used because there was no expected direction of differences in $H$ values. A matrix of genetic dissimilarity between individuals was obtained using 1-Rogers and Tanimoto (1960) similarity index. Nonmetric multidimensional scaling (MDS) was performed to reveal possible groupings of the individuals using the program Statistica 5.1 (StatSoft, 1997). Further, an assignment test was performed on individuals of the two sites using the methods described in Paetkau et al. (1995). The calculator that performs the assignment test for dominant markers is available at http://www.biology.ualberta.ca/old_site/ jbrzusto/Doh.php. The partitioning of molecular variation at the hierarchical levels for which significant departures from the null hypothesis were detected was done by the analysis of molecular variance (Amova, Excoffier et al., 1992). The theoretical basis of Amova is within the context of $U$-statistics (Hoeffding, 1948), and is based on the fact that the sum of squares in conventional Anova can be written as the sum of squared distance between pairs of phenotypes. The distance between individual RAPD phenotypes was a simple Euclidean metric and was calculated by summing the squared differences of pairwise vectors of zeros (absence of bands) and ones (presence of bands) over all polymorphic loci (Excoffier et al., 1992). The phenotypic distances were partitioned into components of variance in the Amova framework and the $\Phi$-statistics (Excoffier et al., 1992) was calculated from the variance component representing variation at the two hierarchical levels designed in this study.

\section{Results}

\subsection{Morphological variation}

The average weights were $0.62 \pm 0.08$ (mean \pm S.E.), 0.24 $\pm 0.02,0.40 \pm 0.03$, and $0.19 \pm 0.01 \mathrm{~g}$ for pond females, pond males, pool females and pool males, respectively. The average total lengths were $33.7 \pm 1.0,27.9 \pm 0.7,31.3 \pm 0.6$, and $25.8 \pm 0.4 \mathrm{~mm}$ for pond females, pond males, pool females and pool males, respectively. Both weights and total lengths were different between the four groups (Anova, $P<0.0001$, d.f. $=234, F=30.71$ for length; $P<0.0001$, d.f. $=234, F=$ 30.39 for weight). A Tukey test as post-hoc test showed significant differences between all pairs $(P<0.05$ in all cases, except for the males of the pond and the pool, whose lengths and weights were not significantly different $(P>$ $0.05)$ and the females of the pool and pond, whose lengths were significantly different $(P<0.05)$. Higher weights in females may have been related to sexual dimorphism and to the fact that most of them were gravid.

Two-way Anova on each morphological parameter was carried out. Gender had an effect on all parameters measured except for AR Fig. 1, Table 2). Females showed lower values of $T_{\mathrm{L}}, T_{\mathrm{A}}, D_{\mathrm{A}}, A_{\mathrm{A}}$ but higher values of $T_{\mathrm{D}}$. Location (pool or pond) had an effect on $T_{\mathrm{D}}, T_{\mathrm{A}}$ and $\mathrm{AR}(P<0.0001$ in all cases), but not on the other parameters $\left(T_{\mathrm{L}}, P>0.5 ; D_{\mathrm{A}}, P>\right.$ $\left.0.05 ; A_{\mathrm{A}}, P>0.1\right)$. The results showed that $T_{\mathrm{D}}, T_{\mathrm{A}}$ and AR were, respectively, higher in pond fish by $29 \%$ (both female and males), 10 and $9 \%$ (females and males, respectively) and 3 and 28\% (females and males, respectively) Fig. 1, Table 2. Significant interactions between location and gender were found only for $A_{\mathrm{A}}(P<0.01)$ and AR $(P<0.001)$.

The possibility that a higher $T_{\mathrm{A}}$ in pond fish may be due to a smaller body area rather than a larger tail area was tested in males, since it is possible that the total body area of females may have been affected by reproductive status. The results showed that the log-log linear regressions between the absolute tail area versus fish length (pond fish: $r^{2}=0.78$, d.f. $=$ 142, $F=150.3, N=44 ; P<0.0001$; pool fish: $r^{2}=0.78$, d.f. $=193, F=327.8, N=95, P<0.0001)$ differed significantly in their elevation $(F=5.55$; d.f. $=1136, P<0.05)$ but not in their 

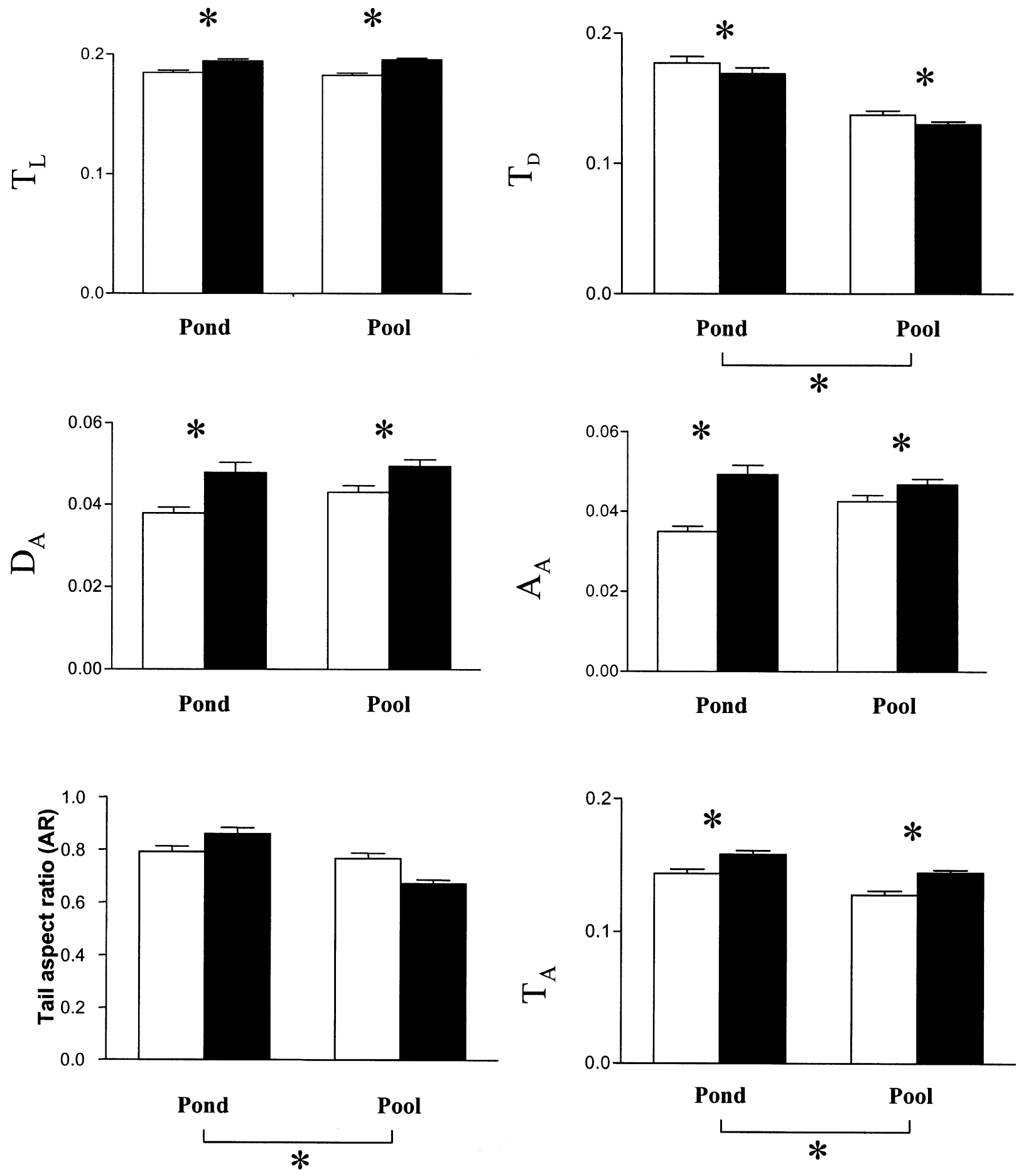

Fig. 1. Main morphological parameters measured in males (filled bars) and females (empty bars) from the pond and the pool. Bars represent means ( \pm S.E.). Asterisks above the bars indicate a significant gender effect. Asterisks below the line connecting pond and pool indicate a significant location effect.

slope $(F=1.74$, d.f. $=1135, P>0.1)$, with the pond fish showing the higher elevation. Conversely, the log-log linear regressions between the absolute total body area versus fish length (pond fish: $r^{2}=0.95$, d.f. $=142 ; F=776, N=44 ; P<$ 0.0001; pool fish: $r^{2}=0.96$, d.f. $=193 ; F=2230, N=95, P<$ $0.0001)$ are not different in slope $(F=0.09$, d.f. $=1135, P>$ $0.1)$ nor elevation $(F=0.5$, d.f. $=1136, P>0.5)$. This sug- gested that the higher $T_{\mathrm{A}}$ in pond fish was due to a higher absolute tail area and not to a lower absolute total body area.

To avoid bias related to the reproductive status of females, fin areas standardised using Length ${ }^{2}$ were also analysed. Two-way Anova was carried out on $T_{\mathrm{A}}$ (tail area/ Length ${ }^{2}$ ), $D_{\mathrm{A}}^{\prime}$ (dorsal fin area/ Length ${ }^{2}$ ) and $A^{\prime}{ }_{\mathrm{A}}$ (anal fin area/ Length ${ }^{2}$ ). The results were consistent with those on $T_{\mathrm{A}}, D_{\mathrm{A}}$ 
Table 2

Results of the two-way Anovas on morphological parameters

\begin{tabular}{|c|c|c|c|c|c|c|}
\hline & & SS & d.f. & MS & $F$ & $P$ \\
\hline \multirow[t]{5}{*}{ Tail length/total length $\left(T_{\mathrm{L}}\right)$} & Intercept & 7.617785 & 1 & 7.617785 & 36652.44 & 0.000000 \\
\hline & Location & 0.000063 & 1 & 0.000063 & 0.30 & 0.582340 \\
\hline & Gender & 0.007538 & 1 & 0.007538 & 36.27 & 0.000000 \\
\hline & Location $\times$ gender & 0.000230 & 1 & 0.000230 & 1.11 & 0.293436 \\
\hline & Error & 0.048011 & 231 & 0.000208 & & \\
\hline \multirow[t]{5}{*}{ Tail depth/total length $\left(T_{\mathrm{D}}\right)$} & Intercept & 5.015380 & 1 & 5.015380 & 7163.906 & 0.000000 \\
\hline & Location & 0.082564 & 1 & 0.082564 & 117.933 & 0.000000 \\
\hline & Gender & 0.003133 & 1 & 0.003133 & 4.475 & 0.035465 \\
\hline & Location $\times$ gender & 0.000028 & 1 & 0.000028 & 0.040 & 0.841634 \\
\hline & Error & 0.161721 & 231 & 0.000700 & & \\
\hline \multirow[t]{5}{*}{ Tail area/total body area $\left(T_{\mathrm{A}}\right)$} & Intercept & 4.394888 & 1 & 4.394888 & 10564.60 & 0.000000 \\
\hline & Location & 0.011602 & 1 & 0.011602 & 27.89 & 0.000000 \\
\hline & Gender & 0.012807 & 1 & 0.012807 & 30.79 & 0.000000 \\
\hline & Location $\times$ gender & 0.000069 & 1 & 0.000069 & 0.17 & 0.684937 \\
\hline & Error & 0.096096 & 231 & 0.000416 & & \\
\hline \multirow[t]{5}{*}{ Dorsal fin area/total wetted area $\left(D_{\mathrm{A}}\right)$} & Intercept & 0.423475 & 1 & 0.423475 & 2102.037 & 0.000000 \\
\hline & Location & 0.000593 & 1 & 0.000593 & 2.943 & 0.087586 \\
\hline & Gender & 0.003537 & 1 & 0.0035378 & 17.55 & 0.000040 \\
\hline & Location $\times$ gender & 0.000172 & 1 & 0.000172 & 0.852 & 0.356825 \\
\hline & Error & 0.046537 & 231 & 0.000201 & & \\
\hline \multirow[t]{5}{*}{ Anal fin area/total wetted area $\left(A_{\mathrm{A}}\right)$} & Intercept & 0.401149 & 1 & 0.401149 & 2449.048 & 0.000000 \\
\hline & Location & 0.000339 & 1 & 0.000339 & 2.071 & 0.151488 \\
\hline & Gender & 0.004642 & 1 & 0.0046422 & 28.34 & 0.000000 \\
\hline & Location $\times$ gender & 0.001386 & 1 & 0.001386 & 8.459 & 0.003987 \\
\hline & Error & 0.037837 & 231 & 0.000164 & & \\
\hline \multirow[t]{5}{*}{ Tail depth/tail length (AR) } & Intercept & 127.3099 & 1 & 127.3099 & 6377.972 & 0.000000 \\
\hline & Location & 0.6361 & 1 & 0.6361 & 31.869 & 0.000000 \\
\hline & Gender & 0.0063 & 1 & 0.0063 & 0.316 & 0.574588 \\
\hline & Location $\times$ gender & 0.3291 & 1 & 0.3291 & 16.489 & 0.000067 \\
\hline & Error & 4.6110 & 231 & 0.0200 & & \\
\hline
\end{tabular}

and $A_{\mathrm{A}}$ Table 22. Gender had an effect on each fin parameter measured.

Females showed lower values of $T_{\mathrm{A}}, D_{\mathrm{A}}^{\prime}, A_{\mathrm{A}}^{\prime}$. Location (pool or pond) had an effect on $T_{\mathrm{A}}$ only $(P<0.0001)$, but not on the other parameters $\left(D_{\mathrm{A}}^{\prime}, P>0.1 ; A_{\mathrm{A}}^{\prime}, P>0.1\right)$. Significant interactions between location and gender were found only for $A_{\mathrm{A}}^{\prime}(P<0.05)$. The results show that $T_{\mathrm{A}}$ is, respectively, higher in pond fish by 14 and 9\% (females and males, respectively) than in pool fish.

\subsection{Genetic variation}

Eight of the 20 primers used yielded band patterns that were clear and could be scored with confidence Table 1. These primers produced 28 variable bands that ranged in size from 400 to $4000 \mathrm{bp}$ Table 1). Frequency of bands varied within and between the two sites. Thirty-two individuals from the pond and 26 from the pool gave acceptable resolution of bands for all primers used. High genotypic diversity was found within populations with only three couples of identical genotypes per population. A greater number of both bands and private bands were found in the pond population and heterozygosity value of the pond population was greater than that of the pool population Table 3. However, the two values did not differ significantly by $t$-test of arcsine square root transformed values $(t=1.776$, d.f. $=54, P=0.081)$. Results of the assignment tests showed that three individuals of the pond (corresponding to 9\%) were incorrectly assigned to the pool population, whereas all individuals of the pool

Table 3

Summary of genetic diversity in the two samples of A. fasciatus

\begin{tabular}{lllllll}
\hline Site & Sample size & Number of bands & Unique bands & Different genotypes $(\%)$ & Heterozygosity $( \pm$ S.E. $)$ & Coancestry coefficient $( \pm$ S.E. $)$ \\
\hline Pond & 32 & 26 & 10 & 90 & $H=0.270 \pm 0.038$ & $\theta=0.301 \pm 0.059^{\mathrm{a}}(P<0.001)$ \\
Pool & 26 & 18 & 2 & 88 & $H=0.231 \pm 0.041$ & \\
\hline
\end{tabular}

${ }^{\mathrm{a}}$ Probability obtained by a permutation test with 10000 replicates. 
Table 4

Results of Amova for 58 individuals of $A$. fasciatus at two hierarchical levels (individuals, population). $P$-values, calculated from a random permutation test (10 000 replicates), represents the probability of obtaining by chance alone a more extreme variance than the observed values (Excoffier et al., 1992)

\begin{tabular}{lclcl}
\hline Source of variation & d.f. & Sum of squares & Variance & Percentage of total variance \\
\hline Among sites & 55 & 287.433 & 9.743032 & 41.13 \\
Within sites & 1 & 766.922 & 13.944043 & 58.87 \\
\hline
\end{tabular}

were correctly assigned. Amova revealed significant molecular differentiation at both within and between site levels Table 4.

To gain further insight into the pattern of molecular variation among individuals, the relationships between pairwise RAPD phenotype dissimilarity, computed as 1-Rogers and Tanimoto (1960) similarity, were subjected to nonmetric MDS. This analysis separated clearly individuals of the pond from those of the pool, with four individuals of the pond distributed in a position intermediate between the two clouds Fig. 2].

\section{Discussion}

\subsection{Morphological variation}

The morphological results showed that pond fish had larger tails than pool counterparts. A larger tail may be beneficial for unsteady swimming manoeuvres such as those employed in predator-prey encounters (Domenici, 2001, 2003). On the other hand, in absence of predators, a large tail may imply costs due to the higher drag associated with increased surface area. (Webb, 1984). Fish in the pond and the pool analysed in the present study are subject to different predation pressures. In fact, individuals of $A$. fasciatus living in the pool are well protected from predation due to the absence of fish predators and abundance of macroalgae that allow to hide and limit predation by birds. Therefore, the observed differences in morphology support the hypothesis that fish living in an environment with high predation pressure may evolve a phenotype that maximises unsteady (escape) swimming performance rather than minimising the

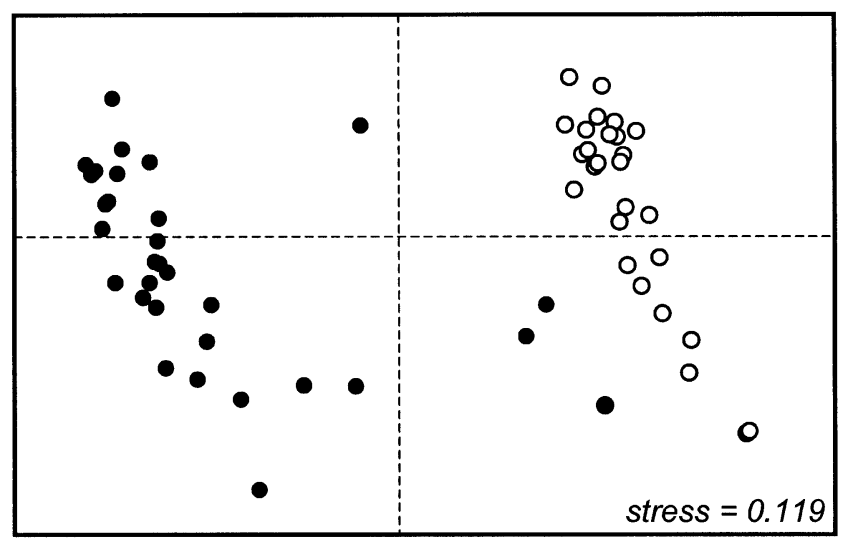

- pond individuals

○ pool individuals

Fig. 2. Nonmetric multidimensional scaling of individuals of A. fasciatus based on genetic dissimilarity matrix [1-Rogers and Tanimoto (1960) similarity] calculated from RAPD data. Black circles are individuals from the pond; empty circles are those from the pool. cost of locomotion. It is not known whether or not this differential predation pressure has existed long enough to allow such morphological divergence to arise as a results of genetic differentiation. Alternatively, the different morphologies may be phenotypically induced within the same generation as in crucian carp (Bronmark and Miner, 1992) and in tadpoles (Smith and Van Buskirk, 1995). As expected, we found no significant differences in fin size in dorsal and anal. As suggested by Webb (1978), a large body depth should be distributed as far as possible from the centre of mass to maximise thrust. This corresponds to having a large tail. A large body depth around the centre of mass (such as that derived from an increased area in dorsal and anal fin) does not necessarily improve fast-start performance, because the amplitude of body movements is minimal at the centre of mass. In addition, while it is possible that different morphologies may have arisen as a result of different predation pressures, this suggestion derives from the assumption based on theoretical grounds (Webb, 1984) that a large tail decreases vulnerability to predation, possibly by improving unsteady (fast-start) swimming performance, although this maybe detrimental for steady swimming performance. However, tests of this theory have produced contradicting results. Plaut (2000) tested the steady swimming performance of zebrafish with different tail sizes. The highest performance recorded was that of wild-type (regular tail size) fish, while large tailed fish had lower performance. This author suggested that drag augmentation due to the larger wetted area of large fins may have been one of the reasons for the lower performance in fish with large tail. While Plaut's (2000) results are in agreement with our assumption, the work by Van Buskirk and McCollum (2000) showed that the unsteady swimming performance of tadpoles with predator-induced morphology (i.e. with large tails) was not significantly different from that of tadpoles of predator-free ponds. Tadpoles are quite different from fish in tail structure and swimming pattern, although they also have Mauthner cells which control their escape responses as in fish (Eaton and Hackett, 1984). Therefore, we consider the study by Van Buskirk and McCollum (2000) a relevant comparison that needs to be taken with caution given the taxonomic distance and morphological differences between tadpoles and fish. In addition, Van Buskirk and McCollum (2000) showed that no difference in performance arose when testing individuals whose tail morphologies had been surgically modified up to $30 \%$ of tail size (fin depth or length). Since naturally occurring differences in tadpole morphology are limited to about $10 \%$ of tail depth, they suggested that the lower vulnerability in tadpoles with predator-induced morphology may be due to 
factors other than swimming performance. For instance, a possible anti-predator function of a large and conspicuous tail may be that it can attract the predator's attention, hence deflecting strikes away from the body and towards the tail region (Caldwell, 1982; Van Buskirk and McCollum, 2000). Our results showing that fish from a pond subject to predation have deeper tails (up to nearly $30 \%$ deeper) than fish from a protected pool are consistent with results on tadpoles, although it is still to be established whether or not such differences are associated with differences in vulnerability. Further studies are needed in order to test whether such differences in morphology are associated with differences in swimming performance. It should be explored whether the morphological differences found are short-term effects such as the predator-induced morphology in tadpoles (Van Buskirk and McCollum, 2000) and crucian carps (Bronmark and Miner, 1992) or related to long-term genetic differentiation.

\subsection{Genetic variation}

Many papers reported the effectiveness of RAPD markers in discriminating between species, subspecies and populations in a wide range of organisms, including fish (i.e. Bardakci and Skibinski, 1994; Allegrucci et al., 1995; Naish et al., 1995; Smith et al., 1997; Gomes et al., 1998; Mamuris et al., 1998). This was confirmed by results of the present study, since high levels of genetic divergence were detected between the two adjacent populations of $A$. fasciatus analysed. A problem arising with the application of the RAPD technique is the homology between co-migrating bands produced by the same primer in different individuals (Hadrys et al., 1992). However, in the present study homology constitutes a valid assumption, since all individuals belong to the same species. The population of $A$. fasciatus at Pilo pond was previously studied for allozyme variation at 13 putative loci, of which seven were polyallelic (Maltagliati, 2002). The estimates of genetic variability, as shown by heterozygosity, obtained with the two classes of markers for the population of Pilo pond were different $\left(H_{\text {allozymes }}=0.117 \pm 0.043\right.$ vs. $\left.H_{\text {RAPDs }}=0.270 \pm 0.038\right)$. However, differences can be due to the properties of the two classes of markers, as for example, codominance versus dominance, rather than having a biological meaning.

Previous investigations based on allozyme data on 11 brackish-water populations of $A$. fasciatus revealed that the overall genetic diversity of the species is almost completely determined by the among-population rather than withinpopulation genetic variability (Maltagliati, 1999). A highly significant coancestry coefficient value was found in that study $(\theta=0.507 \pm 0.078, P<0.001)$ that included populations separated by geographical distances ranging from about 6 to 1000 nautical miles. Surprisingly, in the present study similar levels of between-population genetic divergence have been detected at a much smaller spatial scale.

Recently founded populations are expected to represent a subset of the genetic diversity in the source population leading to the prediction that the founded population should have genetic diversity significantly lower than the source population. The best estimator of within-sample genetic variability is heterozygosity, since the total number of bands and the percentage of different genotypes are more sample-size dependent. Unexpectedly, the two samples exhibited heterozygosities, which did not differ significantly by $t$-test, allowing to reject the hypothesis of the occurrence of founder effect in the population from the pool. This result suggests that multiple colonisation events may have occurred in the past.

The extant high degree of genetic divergence between the populations, as revealed by the occurrence of a number of private bands, the highly significant coancestry coefficient, Table 3 and the Amova Table 4p suggests that colonisation of the pool may be not recent. Unfortunately our data do not allow to provide any reliable estimate of the divergence time. In addition, our results show that the extant physical barrier separating the pond from the pool has been sufficient to prevent migration between the two biotopes and humanmediated translocations of individuals from the pond to the pool can be excluded. Furthermore, as discussed above, another force that may drive genetic divergence could be related to the differences in the predation pressures occurring in the two sites. This may have implied a shorter divergence time between these populations.

A rich literature exists on the influence of macroscopic events such as Pleistocene glaciations on the extinction/ recolonisation processes occurring in large areas and on species genetic structure at continental scale (reviewed in Hewitt, 2000). Nevertheless, other phenomena such as those related to the ecological characteristics of the species or geologically rapid dynamics of brackish-water basins may generate divergence at smaller temporal and spatial scale. The present study showed that important evolutionary events such as population differentiation may occur even at very small spatial scale depending on topographic characteristics of the biotopes and life history features of the species considered. A barrier constituted by a land strip of about $10 \mathrm{~m}$ has been sufficient to promote population differentiation in A. fasciatus of the Pilo pond. It remains to clarify if (i) the population of the pool originated from individuals that colonised the new biotope, (ii) the pool is the remnant of a second proximate ancient larger habitat colonised by another population, or (iii) the pool originated as a propagule of the pond. In conclusion, evolutionary phenomena like population differentiation are of great biological importance, therefore, our results rise questions about the spatial scale to be considered in planning environmental management.

\section{Acknowledgements}

The manuscript has benefited from the comments by M.I. Roldán and two anonymous reviewers. We wish to thank A. Floris for his valuable assistance during the sampling campaign. This work was financially supported by the 1999-2000 inter-university grant by the Italian Ministry of University and Scientific and Technological Research on 
'Environmental stress and biodiversity in brackish-waters'. An Erasmus scholarship allowed C. Franch Fosch to carry out the morphological work at the University of Sassari.

\section{References}

Allegrucci, G., Caccone, A., Cataudella, S., Powell, J.R., 1995. Acclimation of the European sea bass to freshwater: monitoring genetic changes by RAPD polymerase chain reaction to detect DNA polymorphism. Mar. Biol. 121, 591-599.

Archie, J.W., 1985. Statistical analysis of heterozygosity data: independent sample comparisons. Evolution 39, 623-637.

Baillie, J., Groombridge, B., 1996. 1996 IUCN Red List of Threatened Animals. IUCN Publications Service Unit, Cambridge, UK.

Bardakci, F., Skibinski, D.O.F., 1994. The application of RAPD technique in tilapia fish: species and subspecies identification. Heredity 73, 117-123.

Bianco, P.G., 1995. Mediterranean endemic freshwater fishes of Italy. Biol. Conserv. 72, 159-170.

Bronmark, C., Miner, J.G., 1992. Predator-induced phenotypical change in body morphology in crucian carp. Science 258, 1348-1350.

Caldwell, J.P., 1982. Disruptive selection: a tail color polymorphism in Acris tadpoles in response to differential predation. Can. J. Zool. 60, 2818-2827.

Cognetti, G., 1994. Colonization of brackish waters. Mar. Pollut. Bull. 28, 583-586.

Cognetti, G., Maltagliati, F., 2000. Biodiversity and adaptive mechanisms in brackish water fauna. Mar. Pollut. Bull. 40, 7-14.

Council of Europe, 1992. Council Directive 92/43/EEC of 21 May 1992 on the Conservation of Natural Habitats and of Wild Flora. Off. J.E.C., Ser. L 206, 7-50.

Council of Europe, 2000. The Bern Convention. http: //www.nature.coe.int/ english/cadres/bern.htm [access date: 11/7/2002].

Domenici, P., 2001. Scaling the locomotor performance of aquatic vertebrates during predator-prey interactions: from fish to killer whales. Comp. Physiol. Biochem. 131, 169-182.

Domenici, P., 2003. Habitat type, design and the swimming performance of fish. In: Bels, V., Gasc, J.P., Casinos, A. (Eds.), Vertebrate Biomechanics and Evolution. Bios Scientific Publishers, Oxford, UK, pp. 137-160.

Eaton, R.C., Hackett, J.T., 1984. The role of Mauthner cells in fast-starts involving escape in teleost fish. In: Eaton, R.C. (Ed.), Neural Mechanisms of Startle Behavior. Plenum Press, New York, pp. 213-266.

Excoffier, L., Smouse, P.E., Quattro, J.M., 1992. Analysis of molecular variance inferred from metric distances among DNA haplotypes: application to human mitochondrial restriction data. Genetics 131, 479-491.

Ferrito, V., Maltagliati, F., Mauceri, A., Adorno, A., Tigano, C., 2003. Morphological and genetic variation in four Italian populations of Lebias fasciata (Teleostei, Cyprinodontidae). Ital. J. Zool. in press.

Gomes, C., Dales, R.B.G., Oxenford, H.A., 1998. The application of RAPD markers in stock discrimination of the four-wing flyingfish, Hirundichthys affinis in the central western Atlantic. Mol. Ecol. 7, 1029-1039.

Hadrys, H., Balick, M., Schierwater, B., 1992. Applications of random amplified polymorphic DNA (RAPD) in molecular ecology. Mol. Ecol. $1,55-64$.

Hartl, D.L., Clark, A.G., 1997. Principles of Population Genetics. third ed. Palgrave Macmillan Publishers, Houndmills, Basingstoke, England.

Hewitt, G.M., 2000. The genetic legacy of the quaternary ice ages. Nature 405, 907-913.

Hoeffding, W., 1948. A class of statistics with asymptotically normal distribution. Ann. Math. Stat. 19, 293-325.

Kiener, A., Schachter, D., 1974. Polymorphisme d'Aphanius fasciatus Nardo, 1827, (Poisson Cyprinodontidae) des eaux saumâtres. (Populations de Corse et de la lagune italienne de Comacchio). Bull. Mus. Natl. Hist. Nat. $3^{\text {e }}$ ser. No. 212, Zoologie 142, 317-339.
Kirchhoff, S., Sévigny, J.M., Couillard, C.M., 1999. Genetic and meristic variation in the mummichog, living in polluted and reference estuaries. Mar. Environ. Res. 47, 261-283.

Kolding, S., 1985. Genetic adaptation to local habitats and speciation processes within the genus Gammarus (Amphipoda: Crustacea. Mar. Biol. $89,249-255$.

Lynch, M., Milligan, B.G., 1994. Analysis of population genetic structure with RAPD markers. Mol. Ecol. 3, 91-99.

Maltagliati, F., 1998a. Does the Mediterranean killifish Aphanius fasciatus (Teleostei: Cyprinodontidae) fit the one-dimensional stepping-stone model of gene flow? Environ. Biol. Fish. 53, 385-392.

Maltagliati, F., 1998b. A preliminary investigation of allozyme genetic variation and population geographical structure in Aphanius fasciatus from Italian brackish-water habitats. J. Fish Biol. 52, 1130-1140.

Maltagliati, F., 1999. Genetic divergence in natural populations of the Mediterranean brackish-water killifish Aphanius fasciatus. Mar. Ecol. Prog. Ser. 179, 155-162.

Maltagliati, F., 2002. Genetic monitoring of brackish-water populations: the Mediterranean toothcarp Aphanius fasciatus (Cyprinodontidae) as a model. Mar. Ecol. Prog. Ser. 235, 257-262.

Mamuris, Z., Apostolidis, A.P., Theodorou, A.J., Triantaphyllidis, C., 1998. Application of random amplified polymorphic DNA (RAPD) markers to evaluate intraspecific genetic variation in red mullet (Mullus barbatus). Mar. Biol. 132, 171-178.

McCollum, S.A., Van Buskirk, J., 1996. Costs and benefits of a predatorinduced polyphenism in the gray treefrog Hyla chrysoscelis. Evolution $50,583-593$.

Meffe, G.K., Vrijenhoek, R.C., 1988. Conservation genetics in the management of desert fishes. Conserv. Biol. 2, 157-169.

Miller, M.P., 1997. Tools for population genetic analysis (TFPGA) 1.3: a Windows program for the analysis of allozyme and molecular population genetic data. Computer software distributed by the author. .

Muus, B.J., 1967. Some problems facing the ecologist concerning races and subspecies of brackish-water animals. In: Lauff, G.H. (Ed.), Estuaries. American Association for the Advancement of Science, USA, pp. 558-563.

Naish, K.A., Warren, M., Bardakci, F., Skibinski, D.O.F., Carvalho, G.R., Mair, G.C., 1995. Multilocus DNA fingerprinting and RAPD reveal similar genetic relationships between strains of Oreochromis niloticus (Pisces: Cichlidae). Mol. Ecol. 4, 271-274.

Paetkau, D., Calvert, W., Stirling, I., Strobeck, C., 1995. Microsatellite analysis of population structure in Canadian polar bears. Mol. Ecol. 4, 347-354.

Parenti, L.R., Tigano, C., 1993. Polymorphic skeletal characters in Aphanius fasciatus (Teleostei: Cyprinodontiformes). Copeia 1993, 1132-1137.

Plaut, I., 2000. Effects of fin size on swimming performance, swimming behaviour and routine activity of zebrafish Danio rerio. J. Exp. Biol. 203, 813-820.

Rogers, D.J., Tanimoto, T.T., 1960. A computer program for classifying plants. Science 132, 1115-1118.

Smith, D.C., Van Buskirk, J., 1995. Phenotypic design, plasticity and ecological performance in two tadpole species. Am. Nat. 145, 211-233.

Smith, P.J., Benson, P.G., McVeagh, S.M., 1997. A comparison of three genetic methods used for stock discrimination of orange roughy, Hoplostethus atlanticus: allozymes, mitochondrial DNA, and random amplified polymorphic DNA. Fish. Bull. 95, 800-811.

StatSoft, Inc., 1997. STATISTICA for Windows (ver 5.1). Computer Program Manual. StatSoft Inc., Tulsa, OK, USA.

Van Buskirk, J., McCollum, S.A., 2000. Influence of tail shape on tadpole swimming performance. J. Exp. Biol. 203, 2149-2158.

Webb, P.W., 1978. Fast-start performance and body form in seven species of teleost fish. J. Exp. Biol. 74, 211-226.

Webb, P.W., 1984. Body form, locomotion and foraging in aquatic vertebrates. Am. Zool. 24, 107-120. 